of the author is beautifully expressed towards systematic study as a whole. It may truly be said that with the preceding volumes Prof. Bower has now given us a classical study on affinity, replete with suggestion for work on many lines, and marked by a power of expression which many will envy and admire.

J. McL. Thompson.

\section{South African Desiccation and the Bushmen.}

The Kalahari and its Native Races: being the Account of a Journey through Ngamiland and the Kalahari, with a Special Study of the Natives in that Area. By Prof. E. H. L. Schwarz. Pp. $244+24$ plates. (London: H. F. and G. Witherby, 1928.) 16s. net.

$\mathrm{I}^{\mathrm{A}}$ AKE NGAMI has played a conspicuous part in the discussion whether South Africa is undergoing a progressive desiccation which threatens its whole future, or whether the climatic changes that have happened are temporary fluctuations. The late Prof. Schwarz, during his ten years' work on the Geological Survey of Cape Colony, realised the extent to which some parts of the country have been impoverished by drought. He devoted himself to the question of how this alarming process could be checked, and in 1918 published his well-known scheme for the diversion of water from the Zambezi into the great depressions of Lake Ngami and the western Kalahari.

In 1925, while on the Kalahari Reconnaissance Expedition, sent by the Government to investigate his proposals, Prof. Schwarz found the country suffering from floods, and he returned by canoe from the Victoria Falls to Lake Ngami, which was reoccupied by water, and down the Botletle River until it disappeared in the desert; he then, by an arduous waggon journey, crossed the Kalahari to the railway at Palapye. The book describes this journey, which is of special interest, as the country was then restored to the condition familiar from its description by Livingstone. "A country," șays Prof. Schwarz, "that had resigned itself to the condition of permanent drought was for a time gladdened by the sound of rippling water on all sides" (p. 13). A valuable table summarises the history of Lake Ngami from 1760, when it was dry; during the period when it was a great lake, from 1813 to Livingstone's visit in 1849 , when it had then begun to decline; from 1854 until 1861, when it held some shallow water surrounded by reeds; and from 1896 until 1922, when there was no water, and the lake-bed was a dry plain. The restoration of Lake Ngami is regarded as evidence of a cyclic climatic change. The account is conclusive that Africa is not threatened by progressive natural desiccation.

The volume describes important features in the geology of the country. The Zambezi Valley above the Victoria Falls is regarded as a recently made rift valley, seven miles wide, with fault-walls 250 feet high, and to this valley is attributed the diversion of the Zambezi and formation of the Victoria Falls. The basin of Lake Ngami is described as also due to a subsidence bounded by faults of recent date.

Prof. Schwarz's work was always characterised by variety of interest and daring originality, and these features are shown in his interesting account of the Bushmen. Evidence is summarised to show that they ranged all through Africa, and into Asia, and it is claimed that some of the South African natives show Australian and Patagonian affinities. The Mongoloid features of some of them are attributed to settlements of Chinese in East Africa in the tenth and eleventh centuries. This view is supported by reference to the Ming pottery found in Kenya Colony, but it is adequately explained as brought by the Arabs, who had acquired it during the overland trade between China and the Persian Gulf. The migration of Malays to Madagascar is well established; but Prof. Schwarz claimed a Malay origin for the Makalaka who live at the normal end of the Botletle River, and of the Nyam-Nyam of the Upper Nile. In regard to the Hereros, the claim is quoted that their matrilineal descent is due to their ignorance that man has anything to do with parentage, and a more reasonable explanation of that custom is adopted.

The book is a valuable contribution to the recent condition of South Africa by an exceptionally keen observer, who was never afraid of unorthodox deductions.

\section{Our Bookshelf.}

Elements of Optical Mineralogy: an Introduction to Microscopic Petrography. By Prof. Alexander N. Winchell. Third edition, revised and enlarged. Part 1: Principles and Methods. Pp. viii +238 . (New York : John Wiley and Sons, Inc. ; London : Chapman and Hall, Ltd., 1928.) $17 s .6 d$. net.

WiтHIN the last few years there have been marked advances in petrographic-microscopical technique, and Prof. Winchell, in the revised edition of his well-known text-book, has incorporated selected examples in a chapter entitled "Special Methods of Study." Under this heading he deals with the application of Fedorow methods to the study of thin sections, and in addition, the modern dis- 